\title{
İnovasyon ve Girişimcilik Kavramlarının Karşılıklı Etkileşimi"*
}

\section{Öz}

21. Yüzyllda firmaların hedeflerine ulaşmasında inovasyon ve girişimcilik ilişkisi önemlidir. Firmaların rekabet gücünü ve pazar payını artırması, karlılı̆̆ını sürekli kılması, uzun vadede büyümesi bahsedilen kavramların ilişkisinin etkinliğine bağlldır. Yeni ürün, hizmet ve yöntemleri bilgiye dayalı olarak geliştiren firmalar rakiplerine karşı daha avantajlı durumda olacaktır. Girişimci kişilerin doğasında yaratıcllı önemli bir faktördür. Ayrıca girişimcilerin değişimi firsat olarak görmeleri inovasyonu gerçekleştirmelerini kolaylaştırmaktadır. Girişimcileri; pazarlama, örgütsel, sosyal ve iş görenlerle ilgili nedenler inovasyona itmektedir. İnovasyonun tetikleyicisi olarak girişimcilik ruhu önem taşımaktadır. Bu çalışmada firmaların verimli ve etkin çalışmasına, büyüme ve gelişmesine olumlu yönde katkı sağlayan inovasyon ve girişimcilik ilişskisinin pozitif etkileri ele alınıp ayrıntılı bir şekilde incelenmiştir.

Anahtar Kelimeler: Girişimcilik, girişimci, inovasyon, inovasyon çeşitleri.

Jel Kodları: L26, O30, 032.

\section{The Mutual Interaction of Innovation and Entrepreneurship Concepts}

\begin{abstract}
In the 21st century, the relationship between innovation and entrepreneurship has been important for companies to reach their goals. Increasing companies'competitiveness and the market share, continuing of their profitability and their long-term expansion depend largely on the relationship between these two. Companies that develop new products, services and methods based on knowledge will be in more advantageous positions than their rivals. Creativity is an important factor in entrepreneurs' nature. Moreover, regarding a change as an opportunity makes it easier for entrepreneurs to be innovative. Marketing, social, organizational grounds and reasons related to workers, prompt entrepreneurs to be innovative. Entrepreneurial spirit is important trigger for innovation. In this paper, the positive effects of the relationship between innovation and entrepreneurship on the effectiveness, growth and development of companies are studied in details.
\end{abstract}

Keywords: Entrepreneurship, entrepreneur, innovation, innovation types.

Jel Codes: L26, O30, 032.

\footnotetext{
* Bu Çalışma, 1-3 Kasım 2013 tarihleri arasında Muğla'da düzenlenen, Uluslararası Girişimcilik ve Kariyer Sempozyumu'nda bildiri olarak sunulmuştur.

** Öğr. Gör., Çanakkale Onsekiz Mart Üniversitesi, Yenice Meslek Yüksekokulu, E-mail: asahbaz@comu.edu.tr ORCID: http://orcid.org/0000-0001-7423-0819
} 


\section{Giriş}

Girişimcilik bir örgütün kurulması ve faaliyete geçirilmesi sürecidir. Girişimcilikte yaratıcı insan faktörü önemli bir unsurdur. Schumpeter, girişimciliği bir zihniyet şekli değişimi olarak tanımlamıştır. Girişimci, yeni fikirlerin oluşumunda ve uygulanmasında yaratıcılığı ön plana çıkarabilen kişidir. Girişimci belirtilen bu hususların geleceğe taşınmasında da etkili rol oynamaktadır. Girişimcilerin inovatif olmaları ve problem çözebilme becerilerinin olması önemlidir.

İnovasyon, işletmeler açısından risklerin minimize edilmesi, sürekli büyüme ve rekabet avantajı sağlamak için önemli bir kavramdır. İnovasyon yeni ürün ve üretim süreçlerinde olumlu etkiler ve iktisadi faydalar sağlamaktadır. İnovasyon ile risk alma ve başarısızlık olasılığının dikkate alınması gerekmektedir. İnovasyon bu yönüyle girişimcilikle ilişkilidir. Bu nedenle Drucker, girişimcilik ruhunun olmasının inovasyonu olumlu yönde etkilediğini belirtmektedir. Girişimcilerin inovasyona yönelmesiyle; kalite yükselmekte, maliyetler azalmakta, müşteri beklenti ve ihtiyaçları etkili bir şekilde karşılanmaktadır. İşletmelerin inovatif faaliyetlerle daha etkili ve verimli çalışabilmeleri söz konusudur. Ülkeler açısından inovasyon; istihdamın, toplumsal refahın, ekonomik büyümenin, yaşam kalitesinin artırılmasında kilit rol oynamaktadır.

Çalışmamızda inovasyon ve girişimcilik üzerine teorik bilgiler verilerek, iki kavramın etkileşimi ve oluşturduğu sinerji üzerinde durularak değerlendirme yapılacaktır.

\section{2. İnovasyon Kavramı ve Önemi}

İnovasyon (innovation), Latince "innovatus" kelimesinden türemiştir. Yeni yöntemlerin toplumsal, kültürel ve idari alanlarda uygulanmaya başlanması anlamını taşımaktadır. Webster, inovasyonu farklı ve yeni bir sonuç olması boyutunda tanımlamaktadır. Türkçe literatürde, yenilik, yenilikçilik, yenilenme ve Türk Dil Kurumu (2007) tarafindan üretilen "yenileşim" kelimeleri kullanılmaktadır. Ancak bu durumda gerçek anlamı vermemektedir. İnovasyonun sonucu; farklılaştırma ve değiştirmeye bağlı ekonomik ve toplumsal bir sistemi göstermektedir. $\mathrm{Bu}$ durum yenilikçiliğin kendisinden daha fazla önem taşımaktadır (Elçi, 2006:1). Ayrıca yenileşim kelimesinde olan "yeni" kökü bizde bir şeyin eskisinden kurtuluşu olarak anlaşılmaktadır. Oysa inovasyon kavramı piyasada alıcı bulan her ürün için ifade edilebilecek geniş bir tanımlamayı kapsamaktadır. Eski bir modelin farklarla tekrar müşteriye ulaştırılıp satın alınmasının sağlanması da inovasyondur (Keskin, 2012:17).

Cumming (1998) göre (aktaran Gündüz, 2012:90) inovasyonu, bir ürün ya da sürecin başarılı ilk uygulaması şeklinde belirtmektedir. Diğer taraftan Davis ve Devinney (1996) göre (akt. Gündüz, 2012:90) daha değişik bir tanım yapmışlardır. Bu tanımla inovasyon, yeni ya da farklı bir çözüm yolunun yeni ya da var olan bir problemi ve ihtiyacı karşılaması olarak ifade edilmektedir. Davis ve Devinney bu tanımın "yeni ürünler, yeni üretim süreçleri, yeni malzemeler ve kaynaklar, yeni pazarlar ve yeni organizasyon biçimleri" gibi inovasyona yönelik yapılan tanımlarının çoğunu kapsadığını belirtmektedirler. İnovasyonla ilgili farklı yazarlar tarafından yapılmış çok sayıda tanım bulunmaktadır. Dolayısıyla inovasyon homojen bir kavram olma özelliği taşımamaktadır. Çünkü her yazar ilişkili gördüğü unsurları belirterek yeni tanımlar yapmıştır. Örneğin, inovasyonun birçok tanımı üzerine gerçekleştirilen bir incelemede şu sonuçlara ulaşılmıştır: Çoğu araştırmacı inovasyonla ilgili açık bir tanım yapmayı başaramamıştır. Ayrıca kullanılan tanımların birçok kategoriye ayrılabilmesi söz konusudur ve tanımlarda vurgulanan hususların uzun dönemde değişebilmesi mümkündür. 
İnovasyon terimi ile genel olarak yeni geliştirme ve yeni kullanım süreçlerinden biri üzerinde durulmaktadır. Örgütlerde inovasyonun yeni bir parçanın kendisinin geliştirilmesi veya kullanılması süreci başlıca dört adımdan oluşmaktadır. Bunlar yeni fikirler arama, yeni fikirleri değerleme, yeni fikirleri kullanma ve inovasyon geliştirmedir. Ayrıca inovasyon örgütün içinde yaptığı araştırma ve geliştirme faaliyetleriyle sınırlandırılamaz. İnovasyon dış kaynaklarla, sözleşme yoluyla ya da pazar ilişkilerini kullanılması suretiyle geliştirilebilir. Örneğin Apple firmasının çoğu önde gelen inovasyonları (iPod, iTunes, multi-touch) örgütün dışında üretilen teknolojilerin, geliştirilip uyarlanmasıyla gerçekleşmiş̧tir. Bu tür dış inovasyon kaynakları ortak teşebbüsler ve işletme evlilikleriyle sağlanmaktadır (Gündüz,2012:89-91).

İnovasyonun kişilere gruplara veya organizasyonlara sağlayacağı yararlar önemlidir. Gronhaug ve Kaufman'a (1988) göre (akt. Tokmak, 2008:55) inovasyonun gerçekleşebilmesi için yararlı olması ya da yararlı olarak algılanması gerekmektedir. Yararlı olmak; kişilere, gruplara veya organizasyonlara ekonomik çıkar sağlamaktır. Coopey ve diğerlerine göre (1998) (aktaran Tokmak, 2008:55) inovasyonu özellikle "yeni bir şey"in başlangıcı olarak değerlendirilebilecek bir değişim süreci olarak belirtmişlerdir. Bu "yeni bir şey"; ürün, hizmet, teknoloji, yatırım uygulamaları veya organizasyondaki idari süreçlerden herhangi bir tanesi olabilir. Furman ve diğerlerine göre ise (2002) (aktaran Tokmak, 2008:55-56) inovasyonu, başarılı bir şekilde kısmen ya da tamamen yeni ürünler, üretim süreçleri ve hizmetler ortaya çıkarılması ve pazarlanması olarak ifade etmişlerdir. Burada önemli olan inovasyon için her zaman yeni bir ürüne veya hizmete ihtiyaç duyulmamasıdır. Geçmişte farklı bir amaç için üretilen bir ürün, hizmet ya da süreç farklı bir alanda yeniden pazarlanırsa bu da inovasyon olarak değerlendirilebilir. Daha önce üretilen yarı otomatik çamaşır makineleri, tam otomatik çamaşır makineleri geliştirildikten sonra kırsal kesimde yayık makinesi olarak pazarlamıştır. $\mathrm{Bu}$ ise inovasyona örnek oluşturmaktadır.

Drucker (1985) göre (aktaran Tokmak, 2008:56) inovasyonu bir örgütte yararlı bilginin oluşumunda birlikte çalışan farklı bilgi ve yetenekteki çalışanların verimli hale getirilmesi şeklinde tanımlamıştır. Drucker inovasyonu, girişimciliğin özel bir aracı olarak görmektedir. Ekonomist Shumpeter'e göre inovasyon süreci; ticari olarak uygulanabilir fikirlerin, girişimciler tarafindan toplanarak ürüne dönüştürülmesidir.

Çevrenin sürekli değişmesiyle birlikte örgütlerin bu değişime adapte olabilmesi için inovasyona ihtiyaç duyulmaktadır. Bazı işletmeler inovasyon, kapasitelerini artırarak sadece çevreye uymakla kalmayıp, çevredeki bu değişimi yönlendirebilmektedir. Günümüzde iş dünyasında inovasyon; tekrarlanabilir olması, sistemleştirilmesi ve işletmelerin yapısına yerleşmesi açısından önemli bir süreçtir.

Kuczmarski inovasyonu, işletmelerin, geleceği görebilme ve bir gelecek vizyonu oluşturma imkânı olarak ifade etmiştir. Kuczmarski'ye göre inovasyon rekabet avantajı elde etmede önemli bir faktördür. 3M, Apple ve Kellogg gibi işletmeler ünlerini inovasyona önem vermeleriyle sağlamışlardır. $\mathrm{Bu}$ gibi işletmeler inovasyonu işletme stratejilerinin merkez noktası olarak kabul etmişlerdir. Ayrıca Kuczmarski'ye göre inovasyon sadece yeni bir fikirden ibaret değildir. Dolayısıyla inovasyon ile yeni bir fikrin, ticarileşmesi ve bir ürüne dönüşmesi önemlidir. Diğer taraftan inovasyon sürecinde bireysel çabalardan çok, takım çalışması önemlidir. Günümüzde her alandaki hızlı, sürekli ve karmaşık gelişmeler bu durumu kaçınılmaz hale getirmektedir.

$A B$ ve OECD literatürün de inovasyon; "Bir fikri pazarlanabilir bir ürün veya hizmete, yeni ya da geliştirilmiş bir üretim ya da dağıtım yöntemine ve yeni bir toplumsal hizmet yöntemine dönüştürme" olarak belirtilmektedir. Buradaki önemli nokta gerek süreç olarak gerekse sonuç olarak inovasyonun pazarlanabilir olması zorunluluğudur. Dolayısıyla tek başına 
yeni bir fikir, ürün veya süreç pazar koşullarında işletmeye katkı sağlamalıdır. Aksi durumda inovasyon gerçekleştirilesi mümkün değildir (Tokmak, 2008:56-58).

Rekabet ortamındaki artış ivmesi ve değişim süreci sonucunda tüketicilerin istek ve arzuları ani ve hızlı değişimlere uğramaktadır. Diğer taraftan işgücünün pahalı olması üretim teknolojilerinin hızlı ve verimli olmaması gibi unsurlar aynı kalitedeki ürünlerin yüksek fiyatlarda olmasına neden olmaktadır. Bu şartlarda küçük ve büyük ölçekli işletmelerin rekabet gücünü koruması ve rekabet avantajı sağlaması inovasyon yapmalarına bağlıdır. Isşletmeler tüketicilerin gelişen ve değişen ihtiyaçlarına ancak inovasyon yaparak cevap verebilmektedir. Böylece rakiplerini geride bırakabilmeleri mümkün olmaktadır. İnovatif faaliyetlerin sürekli ve sistematik hâle getirilmesi, işletme kültürünün oluşturulmasında önemlidir. Üzerinde durulan yenilik sadece yeni ve farklı bir şeyler oluşturulması değildir. Diğer taraftan işletme için ekonomik değer oluşturabilecek yeniliklerin yapılması da önem arz etmektedir.

Drucker, inovasyon yapamayan büyük bir işletmenin, küçülebileceğini ve yok olabileceğini belirtmektedir. Motorola CEO'su Jeff İmmelt ise kârlılığın tek kaynağının ve bugün ve gelecekte işletmelerin yatırım yapmasının tek nedeninin inovasyon olduğunu vurgulamıştır. Burada işletmelerin inovasyon yapabilme ve farklılık oluşturabilme yetenekleri ön plana çıkmaktadır. Japonya Başbakanı Junichiro Koizumi, Japonya için yeniden doğuşun, sürekli inovasyon ve insan kapasitesiyle sağlanabileceğini belirtmiştir (Işı1k ve Keskin,2013:4446).

\section{3. İnovasyon Çeşitleri}

Literatürde inovasyonu tanımlamak için farklı yazarlar tarafindan çok sayıda sınıflamanın yapıldığı görülmektedir. Dolayısıyla inovasyonu farklı şekillerde sınıflamak mümkündür. $\mathrm{Bu}$ sınıflandırmaların yapılmasında inovasyonun; sıklığı, müşteri ya da firma açısından yenilik derecesi, firma değeri ya da müşteri yararı gibi unsurlar önem taşımaktadır. Aşağıda bazı inovasyon çeşitleri ele alınmıştır.

\section{1. Ürün İnovasyonu}

Ürün inovasyonu, bir işletmenin farklı ve yeni bir ürün geliştirmesi ya da var olan üründe değişiklik, farklılık yenilik yaparak bunu pazara sunmasıdır. Ürün inovasyonu bir işletmenin müşterilerine sunduğu ürün ve hizmetlerde meydana getirdiği değişikliklerdir (İraz, 2005:102). Ürün inovasyonu belirli bir müşteri kitlesinin talebini karşılamak için yeni ürün veya var olan ürünün yeni bir versiyonu pazara sürüldügünde ortaya çıkar (Tavassoli ve Karlsson, 2015:1889).

Ürün inovasyonları işletmelerin rekabetçi konumlarını geliştirmelerini ve pazarda varlıklarını sürdürmelerini sağlamaktadır. Ürün inovasyonuna ihtiyaç duyulması, firmanın organizasyon yapısındaki değişikliklerden de kaynaklanabilir. Örneğin; firmanın güvenlik kontrolleri sayesinde fark edilerek ürün kalitesinin geliştirilmesi sağlanabilir. Diğer taraftan yeni açılan pazarlama bölümleri sayesinde yeni ürünler ortaya çıkabilir. Gıda sektöründe organik ürünlerden hazır yemeğe kadar birçok yeni ürünün pazara sunulması örnek olarak verilebilir. Buna rağmen ürün inovasyonlarının, genellikle süreçlerdeki değişikliklerle ilişkili olduğu vurgulanmaktadır. Ürün inovasyonlarına birçok örnek vermek mümkündür. Örneğin; Elvin Tekstilin gren guard isimli perdesi kir tutmamakta ve uzun süre kullanılmaktadır. Böylece su ve enerji tasarrufu sağlanmaktadır. Ayrıca ilgili firma sivrisinek önleyici, yăg ve leke itici, koku apreli, anti polen ürünleriyle inovasyonlarını sürdürmektedir. Bosch'un su ve enerji 
tasarrufu sağlayan çamaşır makineleri, Vestel'in inventer klimalarına cep telefonundan mesaj atılarak, klimanın önceden istenilen derecede çalışmasının sağlanması, Vestel ve Arçelik' in HD uydu alıcısı ve DVD'si içinde bulunan televizyonları, Samsung buzdolabında LCD ekranların olması, böylece modülden internete girerek yemek siparişi verilmesinin mümkün olması, Samsung LED televizyonlarının sesli kanal değiștirilmesi özellikleri, diğer örnekleri oluşturmaktadır (K1lıç, 2013:63-65).

\subsection{Süreç İnovasyonu}

Süreç kavramı, işletmelerde belirli mal ve hizmetleri üretebilmek için yapılması gereken bir dizi iş ve faaliyet topluluğu şeklinde tanımlandığı gibi farklı türde girdilerden müşteri için değer oluşturacak bir çıktının meydana getirildiği faaliyetlerin toplamı olarak da tanımlanabilir (Marangoz, 2012:53). Süreç inovasyonu üretim süreci maliyetlerini düşürmeyi ve ürün hacmini artırmayı amaçlar (Birasnav vd. 2013:66).

Süreç inovasyonu, mevcut olan iş ve faaliyet topluluklarının gözden geçirilerek yeniden yapılandırılmasıdır. $\mathrm{Bu}$ yeniden yapılanma sonucunda müşteri tatmininin artması gerekmektedir. Eğer müşteri tatmini artmıyorsa süreç yenilemenin etkili olduğu söylenemez. Süreç yenilemede amaç, müşterilerin değer verdiği iş, faaliyet ve konuları geliştirmektir. Böylece müşteri tatmini ve beklentileri daha iyi karşılanacak, bunun sonucunda işletme rekabet üstünlüğü elde edecektir (Ülgen ve Mirze, 2004:390). İşletmeler açısından başkalarının yapamadığ 1 ürünleri daha iyi yöntemlerle yapabilmesi önemli bir rekabet avantajı sağlayacaktır. Böylece rekabet gücünün yükseltilmesi ve iyileştirilmesi sağlanmış olacaktır (Arslan, 2014:19).

\subsection{Radikal İnovasyon}

Radikal inovasyonlar ile pazarın tüketim kalıbı önemli derecede değiştirilmektedir. Radikal inovasyonlar yoluyla teknoloji ile pazar ihtiyaçları uyumlaştırılmaktadır. Örneğin; cep telefonunun kendisi radikal bir ürün olması gibi (Kılıç, 2013:68).

Radikal inovasyon ile yeni ürün, hizmet ve yöntemleri geliştirilmektedir. Ayrıca bu inovasyonun ekonomik faydaya dönüştürülmesi, genellikle yoğun geliştirme çabaları ile gerçekleşmektedir. Radikal inovasyonlar, müşteri ya da endüstri açısından tamamen yeniliği kapsamaktadır (Sat1, 2013:60). Radikal inovasyonlar, müşterilerin kullanmaya başladıkları yeni ürünle birlikte tutum ve davranışlarını önemli ölçüde değiştirmelerine neden olmaktadır (Arslan, 2014:20).

\subsection{Pazarlama İnovasyonu}

Pazarlama inovasyonun da ürün ve hizmetlerde farkl1lık söz konusudur. Değişik bir tasarım, ambalaj ve müşteri ilişkileri yöntemlerinde farklılıklar göze çarpmaktadır. Burada amaç satışları artırmak, yeni pazarlar bulmak, ürünü farklı bir şekilde konumlandırmak, müşteri talebine uygun bir biçimde cevap vermektir. Dünyada www.amazon.com ve ülkemizde www.yemeksepeti.com örnek verilebilir (Keskin, 2012:18-20). Ayrıca Vitra'nın çocuklar için geliştirdiği "Junior banyo" çocuk ergonomisi düşünülerek tasarlanmış ve özellikle anaokulu ve kreşleri hedef alan ürünler pazarlama inovasyonuna örnektir. Bahçıvan gıdanın dilimli beyaz peynirini de örnek olarak göstermek mümkündür (Elçi, 2006:12-13). Ürün veya hizmet gelişimi inovasyonun en bilinen türü olabilir ama diğer türler süreç, pazarlama, lojistik ve işletme inovasyon modellerini içerir. İnternetteki gelişmeler işletmelerin pazarlama kanallarının web 
sitelerini içermesine izin verir ki bu pazarlama inovasyonunu birinci / en önemli örneğidir. Müşteriler, distribütörler ve tedarikçilerle birlikte çalışmaya izin veren stratejik ortaklık işletme modellerinde inovasyonu temsil eder (Robinson ve Stubberud, 2012:54).

\subsection{Organizasyonel İnovasyon}

Organizasyonel inovasyon, bir işletmenin iş yöntemlerini geliştirmesi, farklılaştırması ve yenilemesidir. Ayrıca bu inovasyon ile var olan yöntemlerin işletme şartlarına uyarlanması sağlanmaktadır. Organizasyonel inovasyon ile amaç, maliyetleri düşürmek ve verimliliği artırmaktır (Keskin, 2012:20). Organizasyonel inovasyonlar etkinlik, üretkenlik karlılığ , esneklik ve yaratıcılığı artırmayı hedefleyen, işletmenin rutinindeki değişiklikleri içeren inovasyonlardır (Tavassoli ve Karlsson,2015:1890).

Organizasyonel inovasyon ile işletmelerin iş performansı ilişkisini belirlemeye yönelik yapılan birçok araştırma bulunmaktadır. İlgili araştırma bulguları; organizasyonel inovasyonun uzun dönemli rekabet üstünlüğü sağlamada ki önemini göstermektedir. Bu inovasyon, rekabet üstünlüğü sağlamada iki ana işlevi yerine getirmektedir. Birinci ana işlev, bu inovasyonun teknik düzeydeki ürün ve süreç inovasyonları için bir ön şart olmasıdır. Dolayısıyla bir işletme bu inovasyon çeşidinde başarılı değilse, sürdürülebilir bir ürün inovasyonu oluşturmaz. İkinci ana işlevi ise, bu inovasyonun kendisinin de bir rekabet üstünlüğü aracı olması durumudur. Organizasyonel inovasyon ile taklit edilmesi mümkün olmayan, organizasyonun kendine özgü ve değerli bir öz yetkinliği oluşturulmaktadır (Burmaoğlu ve Şeşen, 2011:3).

\section{6. İş Modeli İnovasyonu}

İş modeli inovasyonunda ise, rakiplerinden farklı bir iş yapma modeli geliştirmek temel amaçtır. İş modeli inovasyonuna lojistik firması UPS örnek olarak verilebilir. UPS ilk defa "kargonuzu gönderdiğiniz kişinin kendisine ulaştırıyoruz" sloganıyla yeni bir iş modeli gerçekleştirmiştir. Böylece sektörde büyük bir değişime neden olmuştur.

IBM şirketinin dünyada 765 yöneticiyi içeren anket çalışmalarında CEO'ların inovasyon ve farklı inovasyon türleri arasında iş modeli inovasyonuna verdikleri önem vurgulanmıştır. Apple şirketi aslında kişisel bilgisayar üreten bir şirket olmasına rağmen bilgisayar piyasasının hızla emtialaşması (aynılaşma) sonucunda iş modelini yeniden tanımlamıştır. Apple müzik işine girmiş ve kendi elektronik, bilgi işleme, saklama ve iletme konularındaki uzmanlıklarıyla pazardaki eksik alanları kapatmıştır. Böylece daha önce akıllara gelmeyen ve öngörülemeyen bir iş modeli icat etmiştir. Apple müzik severler için, içinde daha önce hiçbir cihazın taşımayacağı kadar çok müzik taşıyabilen iPod isimli cihazı geliştirmiştir. Daha sonra bu cihazın karlılığını destekleyecek çevrimiçi müzik dükkânı olan iTunes işini geliştirmiştir. Böylece gençler arasında yaygın olarak internetten müzik indirme alışkanlığı Apple açısından karlı bir işe dönüşmüştür. Bu sayede Apple bilgisayar ürünleri tasarlayan bir şirket olmaktan çıkmıştır. Cihazlar ve hizmetler yoluyla sıra dış1, yeni ve hayran olunan müşteri deneyimleri tasarlayan bir şirket haline dönüşmüştür. Böylece müzik işi Apple firmasının gelirlerinin \%44'ünü ve toplam karlarının yüksek bir payını oluşturmuştur (Kırım, 2007a: 1011). 


\subsection{Deneyim İnovasyonu}

Deneyim inovasyonun çalışma alanını, ürün veya hizmetlere yönelik çeşitli deneyimler oluşturur. Bu inovasyon ile insanlara farklı anlar yaşatmak hedeflenmektedir. Örneğin hizmet sektöründe çoğu firma sattıkları ürünle ilgili müşteriye çeşitli jestler yapmakta ve müşterinin ilgisini çekmektedir. Deneyim inovasyonuna; üçboyutlu film ve bilgisayar oyunları örnek verilebilir (Keskin, 2012:20-21).

İnovasyon, küresel hale gelmiş olan rekabet dünyasında hayatta kalmanın en önemli yollarından birisidir. İnovasyonun bir yönetim modası olarak algılanmaması ve yaşamsal bir gereklilik olduğu konusu önemlidir. Ayrıca eskiden ağırlıklı olarak teknolojik buluşlarla önem kazanan inovasyon günümüzde bu zorunlulukta kurtulmuştur. Günümüzde inovasyon firsatları yeni iş modelleri alanlarında etkisini göstermektedir. Dolayısıyla deneyim inovasyonunu da yeni bir iş modeli oluşturmanın bir yöntemi olarak görmek yerinde olacaktır (Kırım, 2007a:29).

\subsection{Alt Pazar İnovasyonu}

Alt pazar inovasyonu alışagelmişin dışında bir büyüme stratejisidir. Daha önce mevcut pazardaki haliyle bir ürün veya hizmet türünü tüketemeyen kitlelere, ödeyebilecekleri fiyat ve basitlik düzeyinde yeni ürün ve hizmetler geliştirilmesidir. Alt pazar inovasyonu ile yeni karlı büyüme fırsatları oluşturulmaktadır. Alt pazarlarda yeni büyüme ve karlılık alanları bulmak iki farklı şekilde mümkün olmaktadır.

Yeni pazar inovasyonlar: pazardaki mevcut rakiplerin fark etmediği ya da hiç ilgilenmedikleri müşteri gruplarının değerlendirilmesi söz konusudur. Basit içerik ve kullanım özelliklerine olan, uygun fiyatlı ürünler tasarlanmaktadır. Böylece pazarda tüketemeyen kitleleri tüketici haline getirmek amaçlanmaktadır. Bu inovasyonlarda başarı sağlanırsa, çok ciddi büyüme piyasası oluşturulmaktadır. Yeni pazar inovasyonları, "Tüketememe" sorununa çözüm getirmekte yeni büyüme alanları oluşturmaktadır.

Alt-segment inovasyonları: Mevcut ürün pazarında daha henüz yaygın olarak alıcı hale gelmemiş olan kitlelere yönelik iş modeli geliştirmek bu inovasyonlarla mümkün olmaktadır. Burada amaç, pazarın daha düşük gelir elde eden kesimlerine yöneliktir. Çok daha düşük maliyetli bir iş modeli oluşturmaktır. Dacia (Renault) marka otomobillerin Türk pazarına ucuz fiyatlarla girme stratejisi örnek olarak gösterilebilir. Ayrıca Canan kozmetik (ipek şampuanları) ve Ülker firmasının halk marka ürünlerinde aynı stratejiler izlenmiştir. Alt gelir gruplarına yönelik düşük maliyetli ve karlı ürünler geliştirip satmak amaçlanmaktadır. Yukarıda belirtilen örneklerdeki ortak özellik ise pazarın cazip görülmeyen (daha az müşteri) segmentlerine yönelik birer iş modeli tasarlanması ve buna yönelik stratejilerin uygulanmasıdır (Kırım, 2007b: 19-20).

\subsection{Ters İnovasyon}

Dünyada gelişmekte olan büyüme firsatlarını, sil baştan çözümler geliştirerek anlamak ve ele geçirmek mümkündür. Bu açıdan ters inovasyon önemli bir kavramdır. Ters inovasyon sil baştan inovasyon demektir.

Ters inovasyonun en yaygın beş yolu strateji oluşturmak için önemlidir. Beş ihtiyaç farkı ters inovasyon firsatları için bir başlangıç noktasını oluşturmaktadır. Belirtilen bu farklar; performans fark1, alt yapı fark1, sürdürülebilirlik fark1, yasal düzenleme farkı ve tercihler fark1 olarak siralanabilir. 
Gelirlerinin düşüklüğü nedeniyle yoksul ülkelerde ki müşteriler, doğru fiyat karşıllğında performansta ciddi fedakârlıklar yapmaya hazırdırlar. Örneğin; Nokia Hindistan'da müşterilerin yaklaşık beş dolar karşıllı̆ 1 olan fiyatlara satın alabilecekleri düşük maliyetli bir telefon cihazı üretmiştir. Böylece Nokia yüzde altmış gibi çok büyük bir pazar payının oranını yakalamıştır. Nokia küresel rakiplerinin çok sayıda model önerdikleri bir dönemde birkaç temel model üretmiştir. Bu sayede maliyetleri önemli ölçüde azaltmıştır. Nokia ayrıca piyasa için çeşitli uyarlamaları yapmıştır. Hint dili için kısa mesaj yazılmasının sağlanması, cihaza güçlü fener 1şıkları gibi yeni işlevler ekleyerek, elektriğe sahip olmayan kırsal kullanıcıların gereksinimleri karşılanması gibi örnekler verilebilir. Dolayısıyla Nokia gereksinimler arasındaki farkları, özelliklerde performans farkını iyi değerlendirmiştir. Böylece gerekli ihtiyaçları, gerçekçi fiyatlarla karşılayan bir arz yaratılmıştır.

Zengin dünyada altyapı inşa edilmiş durumdadır. Gelişmekte olan ekonomilerde ise altyapı yapılma aşamasındadır. Yoksul ülkelerdeki müşteriler güvenilir ve altyapıya bağlı olmayan çözümlere ihtiyaç duymaktadır. Diğer taraftan yoksul ülkelerdeki altyapıları oluşturan işletmelerin en son teknolojinin çözümlerini anında uygulayabilmesi söz konusudur. Örneğin; Nokia'nın Hindistan'da yüksek pazar payı kazanmasının sebeplerinde bir de kırsal bölgelere gelişmiş kablosuz altyapı yerleştirmesidir. Gelişmekte olan dünyanın kablosuz telekomünikasyona yaptığı yatırımlar önem arz etmektedir. Zira bu sayede yoksul ülkeler bina bankacılığından kriterler için önem taşıyan mobil bankacılığa geçiş yapmışlardır.

Yoksul ülkeler en ciddi sürdürülebilirlik problemlerinin pek çoğuyla karşılaşmaktadır. Bu ülkeler çoğunlukla gelecek kuşağa yönelik çevreye duyarlı çözümlere ihtiyaç duymaktadırlar. Yoksul ülkelerin ekonomik büyümelerinin tek yolu "Yeşil " çözümlerden geçmektedir. Örneğin; Çin'deki elektrikli arabalar konusundaki yoğun çalışmalar, yapılmaktadır. Buradaki amaç ülkedeki olağan üstü hava kirliliğine çözüm getirmektir.

Gelişmekte olan ekonomilerde yasal düzenleme sistem ve yöntemleri daha az gelişmiştir. $\mathrm{Bu}$ sebeple bir işletme pazara yenilikçi çözümler getirmek istediğinde daha az engelle karşılaşmaktadır. Dolayısıyla yeni ürünler yasal düzenleme engellerinden daha kolay geçebilmektedir.

Her ülkenin kendine özgü zevk ve tercihleri vardır. İnovasyon gerçekleştirilirken, bu farklılıklar hesaba katılmalıdır. Gelişmekte olan ülkelerde beslenme alışkanlıklarının vazgeçilmezi olan bazı gıdalar, gelişmiş ekonomilerde seyrek olarak tüketilmektedir. Örneğin; Hindistan'da PepsiCo mısır yerine yine bu ülkede geliştirilen mercimek bazlı gıdalarla tüketilmektedir (Govindarajan ve Trimble, 2012:14-19).

\section{4. İşletmeler Açısından İnovasyonun Olumlu Katkıları}

İşletmelerin inovasyondan beklediği en önemli hedeflerden biri rekabet üstünlüğünü sağlamaktır. Rekabet üstünlüğü yanı sıra ürün ve süreç inovasyonları, işletmeler için gittikçe gereklilik hâline gelmektedir.

Ürün inovasyonunun temelinde yatan, sunulan mal ve hizmetler sayesinde pazar üstünlüğü oluşturmaktır. Araştırma sonuçlarına göre; pazar performansı ve yeni ürünler arasında güçlü bir etkileşim olduğu belirlenmiştir. Pazar paylarının elde edilmesinde, korunmasında ve pazarlarda kârlılığın artırılmasında yeni ürünler etkisini göstermektedir. Bazı etkenler sonucunda en yeni ürünler yüksek getirileri getirmektedir. $\mathrm{Bu}$ etkenleri, küreselleşmeyle artan yabancı rekabet baskısı, teknolojik gelişmeler ile zaman ve mekân engellerinin ortadan kalkması, tüketicilerin genişleyen satın alma alternatifleri, tüketicilerin 
artan bilinçleri olarak sıralamak mümkündür (Gündüz, 2012:120-121).

Günümüzde yalnızca maliyetler rekabet avantajının belirleyicisi değildir. Ürün ve hizmet kalitesi, tasarım, müşteri ihtiyaçlarına göre ürün ve hizmet üretimi, pazarın ihtiyaçlarına cevap verme hızı, yeni ürün ve hizmetlerin geliştirilmesi gibi pek çok etken önem taşımaktadır. Dolayısıyla belirtilen bu etkenler inovasyon yapmayı işletmeler açısından zorunlu kılmaktadır. Yeni pazarlara girmek, pazar payını ve rekabet gücünü artırmak açısından inovasyon anahtar rol oynamaktadır. Bu açıdan sektörü ve büyüklüğüne bağlı olmaksızın tüm işletmelerin inovasyon yapmaları ve inovasyon politikalarının olması önemlidir (Elçi, 2006:27-28).

Yukarıda belirtildiği üzere işletmelerin yaptıkları her türlü işle yeni ve farklılık oluşturacakları çalışmalar içerisine girmeleri zorunludur. Ayrıca işletmeler açısından etkin inovasyonun yeni ilkeleri yüksek fiyat ve bolluk değil satın alınabilirlik ve sürdürülebilirliktir. Hindistan'da Gandi tarzı inovasyonda "satın alınabilirlik" ve "sürdürülebilirlik" odak noktasını oluşturmaktadır. Belirtilen inovasyonun özünde Mahatma'nın iki ilkesi bulunmaktadır. Bunlar, "herkesin yararı için yapılmış her bilim keşfine değer veririm" ve "dünya her insanın ihtiyacını tatmin edecek kadar şey sağlar, ama her insanın aç gözlülüğünü tatmin edecek kadar şey sağlamaz" şeklinde ifade edilmektedir. Ayrıca Hint şirketleri ve kuruluşları devlet desteği ile inovasyona önem vermişlerdir. Bu şirketler birkaç sektörde faaliyette bulunmamaktadır. Her çeşit üretim ve hizmet sektörünü; otomobil üretimi, ilaç geliştirme, sağlık hizmetleri, perakendecilik, bilgisayar tasarım ve kullanımı, su arıtımı, rüzgâr enerjisi vb. çeşit sermaye ve emek yoğunluklarını içermektedir. Bu şirketlerin ortak bağlantıları inovasyon politikalarının olmas1 ve inovasyona önem vermeleridir (Prahalad ve Mashelkar, 2011:13-15).

İnovasyon ile işletme performansı arasındaki ilişkinin çift taraflıdır ve her iki kavramın birbirini etkilemektedir. İnovasyon süreci incelendiğinde, Ar-Ge, üretim ve pazarlama aşamalarının her biri ciddi yatırım maliyetlerini gerektirmektedir. İnovasyon hedefleyen işletmeler bu sürece finansal teknolojik ve beşerî olarak büyük kaynaklar ayırmak zorundadır. Ayrıca inovasyon için kaynak ayırabilecek işletmelerin performansının yüksek ve herhangi bir finansal risk taşımaması önemlidir. İşletmelerin geliştirecekleri özellikle radikal yenilikler, işletmelere pazarda önemli rekabet avantajları sağlamaktadır. Böylece işletmeler rekabet şartlarını belirleyebilmektedir. İşletmelerin pazar payları ise önemli miktarlarda artmaktadır. Ayrıca patent yasaları ile korunan yenilikleri sayesinde uzun vadeli yüksek getiriler söz konusu olmaktadir.

İnovasyon işletmenin büyümesine, kârlılı̆̆ına ve pazar değerinin artmasına yardımcı olmaktadır. Bu noktada da inovasyon ile işletme performansı arasındaki ilişkinin diğer yüzü ortaya çıkmaktadır. Bu durumda da işletmenin rekabet avantajı elde etmesi, pazar payını genişletmesi veya yeni pazarlara girebilmesi için inovasyon yapması gerekmektedir. Dolayısıyla bu iki kavram arasındaki ilişkinin tek yönlü değil çift yönlü, dinamik ve eş zamanlı olduğunu söylemek mümkündür. İnovasyon sayesinde elde edilen yüksek işletme performansı işletmeye önemli kaynaklar yaratmaktadır. Bu kaynakların bir kısmının tekrar inovasyon sürecine aktarılması halinde bu ilişki birbirini besleyerek güçlendirecektir (Tokmak, 2008:109110).

\section{Girişim ve Girişimcilik Kavramı}

Geçmişte kullanılan "teşebbüs" ve müteşebbis" kavramları yerine günümüzde daha fazla "girişim" ve "girişimci kavramları kullanılmaktadır. Latincede "intare" kökünden gelen girişimci kavramı, İngilizcede enter (giriş) ve pre (ilk) kelime köklerinden gelmektedir. İlk (entrepreneur) girişen, başlayan anlamındadır. Belirtilen bu tanım zaman içinde farklılaşmıştır. 
21. yy. da ise "yenilik yapabilme, firsatları değerlendirebilme ve ticari anlamda uygulanabilir hale getirme" olarak tanımlanmaktadır.

Günlük hayatta, girişim (enterprise); bir işi yapmak için harekete geçme, başlama, halini belirtmektedir. Girişimci (entrepreneur) ise; belirtilen durum içinde yer alan girişken kişi anlamındadır. Belirtilen bu kavramlar iktisadi açıdan açıklanmaktadır. Girişimci, arz ve talebi yönlendiren, pazar arayan kişi olarak değerlendirilmektedir. Girişimcilik ise, kaynakların ekonomik olarak kullanılması ve harekete geçirilmesi faaliyetidir (Marangoz, 2012:2). Bir başka tanıma göre girişimcilik; işe, yaşama değer katmadır. Stratejik rekabet açısından geleceği yaratmak için harekete geçen kaynak ve becerileri oluşturarak, değer yaratan bir eylemdir (Ertürk, 2011:15). Drucker girişimciyi, "kendisine ait yeni ve küçük bir işi ya da görevi” yerine getiren kişi olarak tanımlamaktadır. Bu anlamda girişimci, mutlaka sermaye sahibi, yatırımcı ya da işveren demek değildir. Girişimci riski alan ve işi farklı yapan kişidir. Böylece girişimciler, toplumsal kaynakları daha verimli alanlara yöneltmektedir. Bir başka tanıma göre de girişimcilik; yeni ya da mevcut bir organizasyon içerisinde, yaratıcılık ve yenilik yapma yoluyla değer yaratmaktır. Buna yönelik bir fırsatın ortaya çıkarılması ve geliştirilmesi, bu firsatlardan yararlanma süreci olarak tanımlanmaktadır. Bu tanımda girişimcilik hem kişisel hem de işletme bazında değerlendirilmektedir (İlter, 2008:5-7).

Schumpeter, girişimciliği iş dünyasına ilişkin kararlar alma düzeyinde beliren bir zihniyet biçimi olarak ifade etmiştir. Burada girişimcinin yenilikler peşinde koşması ve yenilikler getirebilmesi en önemli özelliğini oluşturmaktadır. Ayrıca girişimcilikten bahsedebilmek için girişime konu olan ürün veya hizmetin pazarlanabilmesi gereklidir. Ürünün ticari anlamda değerli olması ve pazarda benzerinin olmaması veya benzerlerinden farklı özelliklerinin bulunması gerekmektedir. Ayrıca girişimcinin kim olduğu konusuna dikkat edilmelidir. $\mathrm{Bu}$ konuda yapılan tanımların ortak noktası tespit edildiğinde, girişimcinin temel unsurlarının "başkalarının göremediği firsatları görmesi, bunları iş fikrine dönüştürebilmesi" ve "risk almaya yatkınlı̆̆ı” olduğu görülmektedir (Marangoz, 2012:2).

Girişimcinin değişmez belli başlı özellikleri olmalıdır. Bu özellikler; dünya pazarlarına açılabilme boyutunda risk almak, verimliliğe yönelik yeniliklere açık olmak, takım çalışmasına yatkın olmak, sorunlar karşısında sabırlı ve pozitif olmak, gerekli durumlarda inisiyatif kullanabilmek, dünyadaki gelişmeleri izleyip ve bunlara ayak uydurabilmek, hayat boyu öğrenmeyi her zaman benimsemektir. Girişimcinin özellikleri arasında risk tahmini, yenilikçilik, koordinatörlük, organizatörlük ve piyasadaki boşlukları doldurmak da sayılabilir (Bayraktar, 2011:241).

Girişimci kendine güvenen ve çok yönlü bir kişidir. Ayrıca birçok insanın göremediği firsatları görür. İhtiyaçları yenilikçi iş fikirlerine dönüştürür. Bunun yanı sıra girişimci iyi bir dinleyicidir. Çalışanlarını, müşterilerini, tedarikçilerini ve rakiplerini dinleyerek çok şey öğrenirler. Girişimciler hesaplı risk üstlenirler. Risk üstlenmek girişimci tanımlarında en çok vurgulanan özelliktir (Müftüoğlu ve Haliloğlu, 2011:45-46).

Dr. Brian W. ve Dr. Anne Marie Knott'un Management Science'da yayımlanan "Entrepreneviral Risk and Market Entry -Girişimcilik Riski ve Pazara Giriş" başlıklı araştırmalarında; girişimcilerin riskten kaçınan kişiler olduğu fakat şanslarına ve kendilerine aşırı güven duydukları vurgulanmaktadır. Girişimciler toplumun her kesimindeki herkes gibi risk almaktan kaçınırlar. Ancak kendi bilgi, beceri ve yeteneklerine olan güvenleri toplumun diğer kesimlerinden daha fazladır. Girişimcilerde kendine güvenme ve iyimser bakış gücü etkisini göstermektedir (Dalgıç, 2011:283-285).

Girişimci her zaman yeniliklere açık olmalıdır. Sonuçları hızlı değerlendirebilen ve karar 
alabilen kişidir. Karşısındakine güven veren bir yapıya sahiptir. Girişimci teknolojiyi ve sektöründeki yenilikleri takip etmelidir. Bu yenilikleri şirketlerinde etkin kullanabilmelidir. Ayrıca girişimci değişimin gerisinde kalmamalıdır (Uludağ, 2012:22-23).

Çağımızın girişimcilik çağı olmasını sağlayan sebepleri şu şekilde sıralamak mümkündür: ekonomik gelişmeler, demografik faktörler, hizmet sektörünün gelişmesi, teknolojik ve uluslararası fursatların ortaya çıkması, girişimcilik eğitiminin yaygınlaşması, girişimcilik bilincinin gelişmesidir (Müftüoğlu ve Haliloğlu, 2011:20).

\section{6. İnovasyon ve Girişimciliğin Karşılıklı Etkileşimi}

Rekabet anlayışındaki farklılaşmalar, pazar çevresinin değişen şartları, ekolojik gelişmeler inovasyon ve girişimcilik kavramlarının önemini ve karşılıklı etkileşimini daha belirgin hale getirmektedir. Aşağıda hem firmalar hem de ülkeler açısından önemi giderek artan bu iki kavramın karşılıklı etkileşimi incelenmiştir.

\section{1. İnovasyon ve Girișimcilik Arasındaki Kavramsal Çerçeve}

Girişimcilikve inovasyon arasındaki kavramsal ilişki uzun yıllar literatürde tartışılmıştır. Son yıllarda özelikle ekonomideki inovasyon artışları dikkat çekmiştir. İktisadın temel kuramları özetlenmiş ve inovasyon tartışmaları mevcut teorik yenilik ve belirlenen üç rakip paradigma ile tanımlanmıştır (Zhao, 2005:28).

$\checkmark$ Girişimci paradigma

$\checkmark$ Teknoloji- ekonomi paradigma

$\checkmark$ Stratejik paradigma.

Girişimci paradigma kökeni 1930'larda araştırılmıştır. Schumpeter girişimciler ve inovasyon arasında bir bağlantı kurmaya çalışmış ve yenilikçi girişimcileri izlemiştir. Schumpeter girişimcilerin inovasyon ürettiği için ekonominin büyümesine katkı sağladığını iddia etmiştir.

Girişimci paradigmada inovasyon sürecinde girişimcinin rolü belirtilmiştir. $\mathrm{Bu}$ paradigmaya göre, sadece bir kişi yeni bir fikir temelinde yeni bir şirkette bulunabilir ve buna bir girişimci denir. Girişimcilik yaratıcılık ve yenilik olarak görülmektedir. Girişimcilik daha önce olmayan bir şey yaratmaktır. Bu yaratıcılık birey ve topluma değer katan algılamalar ve firsat yakalamaya dayanmaktadır. Bygrave ve Hofer benzer görüşlere sahiptir. Onlar, devletteki bir değişiklikle girişimciliği dinamik bir süreç ve eşsiz bir etkinlik olarak kabul etmiştir. Legge ve Hindle organizasyon takımlarının başında inovasyonların tanıtımında girişimcilere inanmaktadir.

Girişimciler firsatları arayarak ve yenilikçi araçlarla başarılı olabilir. Kurumsal girişimcilik genellikle yeni bir fikir, yeni ürünler, yeni organizasyon yapısı, yeni bir üretim süreci veya yeni bir organizasyon mevcut bir örgütün kurulması anlamına gelmektedir. Herbing inovasyona gerekli üç temel bileşeni incelemiştir: bunlar altyapı, sermaye ve girişimcilik kapasitesidir. İnovasyon farklı bir iş veya hizmet de bir fursat olarak girişimciliğin özel bir aracıdır. Ayrıca, inovasyon pazar ihtiyaçlarını karşılamak için vardır ve ticari başarım elde etmek için ise girişimcilik gereklidir.

İnovatif girişimleri merkeze koyan bir eko sistemin oluşturulması önemlidir. Firmaların 
sadece Ar-Ge'yi önemsemesi kazanca dönüşeceğinin garantisini oluşturmamaktadır. $\mathrm{Bu}$ doğrultuda, girişimcilik boyutunda öncelikli olarak yapılması gereken hususlar bulunmaktadır. İlk olarak girişimciler ve firmaların gelişim sürecinde danışmanlık hizmeti almaları özendirilmelidir. İlgili danışmanlık hizmetinin iş, süreç, hukuk ve pazarlama vb. alanlarda verilmesi daha uygun olacaktır. Diğer taraftan sivil toplum kuruluşları ve medya aracılığıyla farklı düşünme ve inovasyon teşvik edilmelidir. Üniversitelerin altyapı ve bilimsel gelişmeleri gerçekleştirmelerinin yanı sıra girişimciliği ve sanayiyi desteklemeleri de gerekmektedir. Fikirlerin kazanca dönüştürülmesi amacıyla girişimcilerin tüm süreçlerde desteklenmesi gerekmektedir (Müsiad, 2012:150-152). Ülkelerin girişimciliğge gereken önemi vermeleri ve girişimciliğin önündeki olumsuz engelleri ortadan kaldırmaları önemlidir. Bunun gerçekleştirilmesi faaliyette bulunan bütün sektörlere önemli avantajlar sağlayacaktır. Girişimci ve girişimci kültüre atfedilen önem ve pay; yeni fikirler üreten ve sunan firmaların başarısını artırmaktadır (Uçkun ve Girginer, 2012:99).

\section{2. İnovasyon ve Girişimcilik İlişkisi}

Girişimciler, firsatları başarıyla dönüştürebilmek için inovasyondan yararlanmalıdır. Girişimciler açısından; demografik değişimler, kültürlerin karışması, küreselleşme, teknolojik değişim ve gelişmeler gibi unsurlar yeni firsatlar oluşturmaktadır.

Avustralya 'National Innovation Summit 2000'de yapılan inovasyon tanımlarından birisinde; yeni bir fikrin geliştirilerek ve hayata geçilmesi vurgusu yapılmaktadır. İnovasyon ile ilgili bilgi geliştirme ve uygulama boyutları üzerinde durulmaktadır. Yeni bir endüstri ve aktivitenin geliştirilmesi anlaşılabileceği üzere var olanların dönüştürülmesiyle mümkündür. Dolayısıyla yeni örgütsel düzenlemelerin yapılması ve teknolojik değişimde gereklidir. Keşfetme, öğrenme, bilginin yeni şekillere dönüştürülmesi, değişim, araştırma, geliştirme uygulama gibi hususlar önemlidir. Bu bağlamda inovasyon, girişimcilerin vazgeçilmez en önemli araçlarından birisidir (Orhan, 2012:33).

Girişimcilikte, işe yönelik fırsatları tanımak ve değerlendirmek için uygun bir risk yönetimine ihtiyaç vardır. Diğer taraftan iletişim ve yönetsel yetenekleri kullanarak değer yaratmak önemlidir. Bu durumda girişimci yeni fikirlerin oluşturulmasında, tasarlanmasında ve uygulama aşamasında önemli roller üstlenmek durumundadır. İşletmelerin büyüme aşamalarında, girişimcilerinin inovasyon odaklı olmaları ve fikir aşamasındaki inovasyonları uygulamaya dönüştürmeleri önem taşımaktadır.

İnovasyon, hem tüm işletme risklerinde başarı elde etmek hem de girişimcilik için önemlidir. İşletmelerde beklenmeyen durumlarda ortaya çıkan problemleri çözme yeteneğini inovasyonla ilgilidir. Günümüzde pazarı artık dünyanın bütünü oluşturmaktadır. Bunun sonucunda rekabet şartları ağırlaşmakta, teknolojide hızlı değişimler yaşanmakta, pazarlar ve müşteri talepleri hızla değişmekte ve ürünler hızla eskimektedir. Değişimin hızlı olması sebebiyle, girişimcilerin rekabet gücünü sağlamaları yeterli değildir. İşletmelerin rekabet üstü olmaları başarıyı beraberinde getirecektir. Dolayısıyla işletmeler açısından inovasyon, günümüz pazarlarında bir süreç olarak zorunluluk haline gelmiştir.

Lundvall: İnovasyon kavramını geniş bir biçimde tanımlamıştır. Lundvall'a göre; üründe, süreçte, yönetsel ve örgütsel, pazarda yenilik olarak sınıflandırılmaktadır. Üründe yenilik mal, hizmet ve fikirlerdeki değişiklik ve inovasyonları kapsamaktadır. Süreçte yenilikte ise teknoloji ve alt yapı etkisini göstermektedir. Yönetsel ve örgütsel yenilik pazarlama, satın alma ve satış, işlerin yapılma şekli, yönetim şekli ve personel politikalarıyla ilgilidir. Pazarda yenilik yeni pazar alanlarının bulunmasını ve pazar alanlarına nüfuz edilmesini kapsamaktadır. Ayrıca 
belirtilen yenilik türleri birbiriyle etkileşim içerisindedir. Diğer taraftan inovasyon ile risk alma ve başarısız olma ihtimali söz konusudur. Belirtilen bu hususlar girişimcilikle yakından ilgilidir. $\mathrm{Bu}$ bağlamda, Drucker inovasyonun tetikleyicisi olarak girişimcilik ruhunu belirtmektedir. Girişimciler inovatif faaliyetlerle, yapı, süreç, mal ve hizmetlerde değişimler yaparak maliyeti azaltmaktadır. Ayrıca kalitenin yükseltilmesiyle müşteri istek ve ihtiyaçları daha etkin bir biçimde karşılanmaktadır. Süreçlerde ve yönetsel faaliyetlerde yapılan inovasyonlar, işletmelerin daha etkin ve verimli çalışmasını sağlamaktadır. Bahsedilen olumlu sonuçlar büyümeyi ve gelişmeyi sağlamakta ve ulusal ekonomiye pozitif yönlü katkı sağlamaktadır. İnovasyonda başarı sonucunda sürdürülebilir büyüme, toplumsal refah ve yaşam kalitesi artmaktadır. Ayrıca işsizlikle mücadele ve istihdamın sağlanmasında önemli bir araç olmaktadır (İrmiş ve Özdemir, 2011:139-140).

Schumpeter, iktisadi kalkınmayı anlamada girişimciliğin çok önemli olduğunu belirtmiştir. İktisat bilimi girişimciyi, arz ve talebi yönlendiren, pazar arayan kişi olarak tanımlamaktadır. Girişimcilik ise kaynakları ekonomik olarak kullanabilme ve harekete geçirme faaliyetleridir. Schumpeter, girişimcinin inovasyona olan etkileşimine vurgu yapmaktadır. Günümüzde ekonomik iş birliğine dayalı ortaklıklarda (Avrupa Birliği ve OECD) rekabetlerini sürdürebilmek için girişimci faaliyetleri desteklemektedir (Mercan, 2011:33).

İnovasyonun ortaya çıkması iki biçimde olmaktadır. Birincisinde belli bir konu hakkında araştırma ve deneyler yapılmaktadır. Böylece yeni bilgilerin üretilmesi sağlanmaktadır. Başka bir ifadeyle Ar-Ge'ye yönelik yatırımlar yapmak en temel inovasyon oluşturma biçimidir. İkincisi ise başkalarının yaptığı inovasyonların transfer edilerek bilgi sağlamasıdır İlk durum çok gelişmiş ülkeler tarafından gerçekleştirilmektedir. Oysa gelişmekte olan ülkeler kendi inovasyonlarını üretememektedir. Çünkü bu ülkeler yetersiz ve niteliksiz fiziksel ve beşerî sermaye birikimine ve finansman sorunlarına sahiptirler. Dolayısıyla gelişmekte olan ülkeler çoğunlukla gelişmiş ülkelerden inovasyon transfer etmektedir. İthalat veya doğrudan yabancı yatırımlarla teknoloji ve beraberinde bilgi transfer edilmektedir (Tüylüoğlu ve Saraç, 2012:40).

İnovasyonun uluslararası olması boyutunu finans kaynakları, üretim ve dağıtımın küreselleşmesi sağlamıştır. Ar-Ge yatırımlarını artıran uluslararası işletmeler buna zemin hazırlamışlardır. Ayrıca 1990'lı yılların sonlarından itibaren inovasyonun uluslararası olması durumu yükselen ekonomilerde varlığını hissettirmektedir. Bu yükselen ekonomiler, Güneyde, Doğu'da ve Güneydoğu Asya'da etkisini göstermektedir. Yerel ve ulusal işletmeler Ar-Ge faaliyetleriyle yeni ürün ve süreçlerdeki yaratıcılıklarıyla inovasyonun kaynağını oluşturmaktadır.

İnovasyonun uluslararası olmasında başka bir bakış açısını yeniliğin transfer edilmesi oluşturmaktadır. Gelişmekte olan ülkelerin girişimcileri, gelişmiş ülkelerin yaptıkları inovasyonları (yeni teknoloji) transfer etmektedirler. Bu ise gelişmiş ülkelerin teknoloji ve teknik transfer ederek, büyük miktarlarda gelir sağlamasına zemin hazırlamaktadır. Diğer taraftan üretim zinciri içerisinde gelişmiş ülke işletmelerinin, gelişmekte olan ülke işletmelerini daha yeni olanını üretme konusunda yönlendirmeleri, birbirleriyle rekabet ettirmeleri söz konusudur.

Ayrıca gelişmiş ülkeler, genellikle üretmiş oldukları en son teknolojiyi ellerinde tutarak korumaktadır. Böylece eskiyen teknolojiler, gelişmekte olan ülkelerin işletmelerine transfer edilmektedir. Az gelişmiş olan ülkelerde yeniliğin ve Ar-Ge'nin gelişmiş ülkeler ve onların işletmeleri tarafından yönlendirilmesi söz konusudur. Belirtilen kısır döngü gelişmiş ülkeler ile az gelişmiş ülkeler arasındaki farkın kapatılamayarak daha da artıyor olması sonucunu doğurmaktadır. Ayrıca teknolojik bağımlılık tek yönlü olarak devam etmektedir (İrmiş ve Özdemir, 2011:141). 


\section{3. İnovasyon Disiplini Boyutunda Girişimcilik}

"Girişimci kişilik" girişimcilerde olması gereken özellikler arasındadır. Ancak girişimcilerin pek azında bu tür kişilik bulunmaktadır. Buna karş1lık girişimci olmayan böyle kişiliklere sahip çeşitli mesleklerde çalışan insanlar vardır. Fakat başarılı girişimcilerin ortak noktası, belirli türden bir kişilik olmasıyla değil, sistematik inovasyon uygulamasına olan bağlılıklarıdır. Şunu da belirtmek gerekir ki inovasyonla birlikte girişimcilerin, girişimcilik stratejilerini ve girişimcilik yönetim ilkelerini kullanmaları da önemlidir. Firmalarda, kamu hizmeti kuruluşlarında ve kişilerin başlattığı yeni atılımlarda inovasyon girişimcilik açısından önemlidir. İnovasyon, girişimcinin yeni refah sağlayıcı kaynaklar oluşturmasında ya da mevcut kaynakları ek potansiyele dönüştürmesinde kullandığı bir araçtır.

Başarılı girişimciler inovasyon fikirlerinin oluşmasını beklemezler. Başlıca yedi kilit alanda inovasyon firsatlarını aramaktadırlar (Drucker, 2011:211).

Beklenmedik Olaylar: Bunlar genellikle hataları içermektedir. Beklenmedik başarısızlıklar inovasyon firsatı kaynağı olabilir. Örneğin; Edsel Otomotiv Ford'un tarihindeki en büyük yeni araba başarısızlığıdır. Ancak bu başarısızlık şirketin daha sonraki başarısının alt yapısını oluşturmuştur. Ford General Motors'la rekabet edebileceği Edsel'i tasarlamıştı ve Amerikan otomotiv tarihindeki en özenli tasarımdı. Edsel'in başarısızlığında; Ford otomobil pazarının artık gelir gruplarına göre değil yaşam tarzlarına göre bölümlere ayrıldığını fark etmesidir. Bunun sonucunda Ford Mustang üretimini yapmıştır. Mustang şirkete özel bir kişilik kazandırmış ve sektör lideri konumuna getirmiştir.

Beklenmedik başarısızlıkların verimli inovasyon fırsatlarına dönüşmesi birçok şirketin bunları bir yana bırakması, görmezlikten gelmesi, karşı çıkması gibi nedenlere dayandığı görülmektedir.

Risk alma arzusu ve başarısızlıklar karşısında gösterilen tepkiler, ülke kültürlerine göre farklıdır. Bazı kültürlerde başarısızlığın yaratacağı olumsuz etkiler çok büyüktür ve kişiler risk almak istemezler. $\mathrm{Bu}$ durumda kişiler hayal kırıklığına yol açabilecek herhangi bir şeyi denemek istemezler. $\mathrm{Bu}$ durumda kişilere belli bir başarı sağlaması garanti olan yolları izlemeleri öğretilir. Örneğin Tayland' da üst üste başarısızlığa uğramış bir kişi hayatını yeni baştan kurmak için adını değiştirmektedir. Silikon vadisinde ise başarısızlık teknoloji geliştirme sürecinin doğal bir parçası olarak kabul edilmektedir. Başarısızlığ girişimcilik açısından da önemlidir (Seelig, 2010:67-68).

Bağdaşmazlıklar: Beklentiler ile sonuçlar arasındaki bir bağdaşmazlık inovasyon imkânları yaratabilir. 20. Yüzyıl başlarından itibaren 50 yıl süresince, gemi yapımcıları ve gemicilik şirketleri daha hızlı gemi ve yakıt tasarrufu ile ilgili çalışmalar yapmışlardır. Sağlanan başarı sonucunda okyanus şileplerinin ekonomisi (1950 y1llarda) bozulmuştur.

1960 yıllarda katarakt ameliyatı bir bağ dokusunun ileri teknoloji ile kesimi dışında, göz cerrahları için eski moda faaliyetlerdir. Alcon laboratuvarlarında bağ dokusunu çözen bir enzimi değişime uğratarak çözüm getirmiştir. Böylece cerrahlar yeni ürünü benimsemişler ve Alcon bu alanda bir tekel haline gelmiştir.

Süreç Gerekleri: 1890'larda geçekleşen iki süreç inovasyonu, bugün bilinen medyanın oluşturulmasına yol açmıştır. Linotip gazetelerin hızlı üretilmesini ve çok sayıda basılmasını mümkün kılmıştır. Bu gelişmeler sonucunda reklamcılık, bu gazetelerin pazarlamadan gelen karları sayesinde ilerleme kaydetmiştir. Ayrıca haberleri bedava dağıtmalarını sağlamıştır.

Sektör ve Pazar Değişimleri: Sektör yapılarının değişimleri inovasyon için büyük firsatlar oluşturmaktadır. Örneğin sektör yapısındaki değişimler Amerikan sağlık 
kuruluşlarında (son 10-15 yıl) kapsamlı inovasyon firsatları yaratmıştır. Ülkenin çoğu bölgelerinde bağımsız cerrahi, psikiyatri klinikleri, acil durum merkezleri ve sağlık yönetimi kuruluşları açılmıştır. Sektörlerin yapısı değişirken yerleşik şirketler savunmaya odaklanmakta ve yeni rakip kendilerine meydan okuduğunda karşı atağa geçmemektedir. Böylece pazar ve sektör yapılar değiştiğinde, geleneksel sektör lideri en hızla büyüyen pazar dilimlerini ihmal etmektedir. Bu nedenle inovasyon liderlerinin uzun süre yalnız kalma şansları vardır.

Demografik Değişimler: İnovasyon firsatı ile ilgili dış kaynaklardan en güvenilir olanı demografidir. Çünkü nüfus hareketlerinin bilinen öngörü süreleri vardır. Japonların robot bilimindeki ilerlemelerinin sebebi nüfus bilimine önem vermeleridir. 1970'lerde gelişmiş ülkelerdeki doğum oranlarında bir düşüş ve eğitim patlaması yaşanacağı biliniyordu. Gençlerin yarısı ya da biraz fazlası liseden sonra eğitimini sürdürüyordu. Bunun sonucu olarak 1990'larda üretimdeki geleneksel işçi sayısı azalacak ve yetersiz hale gelecektir. Bunun bilinmesine rağmen Japonlar bu konuda gerekeni yapmış ve robot biliminde lider konuma gelmişlerdir. İnsan sayılarındaki, yaş dağılımındaki mesleklerdeki ve coğrafi yerleşimlerdeki değişimler inovasyon fırsatları oluşturmaktadır. Ayrıca bu inovasyon firsatları girişimcilik çabalarına en yüksek karşılık veren ve en az riskli olanıdır.

Algı Değişimleri: Algılamadaki bir değişim olguları değiştirmez. Ancak anlamlarını büyük ölçüde değiştirebilir. Şöyle ki Amerikalılar son 20 yılda sağlık sektöründeki büyük iyileşmelere rağmen hastalıkları önlemek ve sağlıklı kalmak adına takıntılar oluşturmuşlardır. $\mathrm{Bu}$ durum sağlık algısını çözen inovasyon liderleri için inovasyon firsatları doğurmuştur. Örneğin, yeni sağlık dergileri, sağlıklı yiyecekler, jimnastik dersleri hafif koşu araçları pazarlarını oluşturmuştur.

Yeni Bilgi: Bilimsel, teknik, toplumsal yeni bilgiler çı̆̆ır açıcı inovasyonlar arasında yer almaktadır. Ayrıca bunlar girişimcilik açısından çok önemlidir. Çünkü reklam ve para getirileri vardır. Bu yönüyle diğer inovasyonlardan farklıdır. Tasarım-üretim aralığına sahiptirler. Yani, yeni bilgilerin ortaya çıkmasıyla bunun kullanılabilmesi, teknolojiye dönüştürülmesi uzun bir sürece bağlıdır. Ayrıca bu yeni teknolojinin piyasada ürün, süreç veya hizmet olarak ulaşması da uzun bir süre gerektirebilir. Bütün bunların etkili olması için bu inovasyon türünde birçok bilgiye ihtiyaç duyulmaktadır. Zor olmasına rağmen bilgiye dayalı inovasyonun yönetilmesi mümkündür. Ayrıca bilgiye dayalı inovasyon diğer inovasyon türlerinden daha fazla pazara bağımlıdır (Drucker, 2011:211-219).

\section{Sonuç}

Günümüzde değişen çevresel koşullar ve hızla gelişen rekabet ortamında, işletmeler sürekliliğini sağlamak için farklı yollar aramaktadırlar. Ürünlerin, hizmetlerin, yöntemlerin değiştirilmesi, yenilenmesi, yeniden tasarlanması işletmelerin rekabet avantajı sağlaması açısından önemlidir. İnovasyon işletmelerin pazar paylarını, karlılıklarını, kalitelerini olumlu yönde etkilemektedir. Bu ise işletmelerin önemli performans artışlarına imkân sağlamaktadır. Ayrıca işletmelerin uzun dönemde rekabetçi kalabilmelerini mümkün kılabilmektedir. Değişimi firsat olarak görme ve yaratıcılık girişimcilerin doğasında var olan özelliklerdir. Bu ise rekabet avantajının kazandırılmasını yani inovasyonun gerçekleştirilmesini kolaylaştırmaktadır. Girişimcileri pazarla ilgili, örgütsel, sosyal, işgörenlerle ilgili nedenler inovasyona itmektedir. İnovasyonun oluşumunda girişimcilerin firsatları değerlendirmeleri ve başarı elde etmeleri önemlidir. Demografik değişimler, kültürlerin karışması, dünyanın küçülmesi, teknolojik gelişmeler, iletişim ağlarının oluşturulmasına yönelik değişimler; girişimcilere önemli avantajlar sağlamaktadır. 
Çalışmada, girişimcilerin vazgeçilmez en önemli araçlarından birisinin inovasyon olduğu vurgulanarak, kavramların olumlu etkileşimlerinin sonuçları üzerinde durulmuştur. Ayrıca inovasyon, tüm işletme risklerinde başarı sağlanmasında ve girişimcilik açısından önem taşımaktadır.Girişimciliğin inovasyonun oluşumuna, ekonomik kalkınmaya, yeni işletme ve yeni sektörlerin oluşumuna, büyüme ve istihdama olan katkıları önem arz etmektedir. $\mathrm{Bu}$ bağlamda çalışmamızda belirtilen, Gandi tarzı inovasyonda ki bakış açısı ve başarı önemlidir. Burada ki çok çeşitli sektörlerde faaliyet gösteren işletmelere inovasyonun gelişimine yönelik devlet desteği verilmesi ve ulusal inovasyon politikalarının olması dikkate alınmalıdır.

\section{Kaynaklar}

Arslan, M. (2014). İnovasyon Düşünmenin Zirvesi, Final Yayıncılık, 1. Baskı, İstanbul.

Bayrakdar, S. (2011). “Avrupa Birliği Mesleki Eğitim Programlarında Girişimcilik Eğitimlerinin Ekonomik Kalkınmadaki Önemi”, C. Ü. İ.İ.B.F. Dergisi, 12(1):241-264.

Birasnav, M. \& Albufsala, M. \& Bader, Y. (2013). "The role of transformational leadership and knowledge management processes on predicting product and process innovation: An empirical study developed in Kingdom of Bahrain”, Review of Applied Management Studies 11, s.64-75.

Burmaoğlu, S. \& Şeşen, H. (2011). "Türk Firmalarının Organizasyonel İnovasyon Yeteneğini Etkileyen Faktörler Üzerine Bir Araştırma”, Ankara Üniversitesi, SBS Dergisi, 66(4):120 .

Coopey, J. \& Keegan O. \& Embler, N. (1998). "Managers' Innovations and the Structuration of Organization", Journal of Management Studies, Say1 35, s.263-284.

Cumming, B. S. (1998). "Innovation Overview and Future Challenges," European Journal of Innovation Management, $\mathrm{C}: 1, \mathrm{~S}: 1$.

Dalgıç, T. (2011). “İşletmecilik ve Pazarlama Yazıları,” Beta Yayınları, İstanbul.

Devinney, T. N. \& Davis, J. "The essence of corporate strategy," (Çevrimiçi) http://www.agsm.unsw.edu.au/ timdev/toc.htm, 04.03.2009 saat 09:15.

Drucker, P. F. (2011). “İnovasyon Disiplini”, Çev. İlker GÜLFIDAN, Harward Business Review, Mess Yayınları, Yayın No:631, İstanbul.

Drucker, P. F. (1985). Innovation and Entrepreneurship, Harper\&Row Publishers, Newyork.

Elçi, Ş. (2006). "İnovasyon Kalkınmanın ve Rekabetin Anahtarı”, Nova Basım, Yayın Dağıtım, Ankara.

Ertük, M. (2011), “İşletme Biliminin Temel İlkeleri”, Beta Yayınları, İstanbul.

Furman, J. F. \& Porter M. E. \& Stern, S. (2002). "The Determinants of National Innovative Capacity," Research Policy, Say1 31, s.899-933.

Govindarajan, V. \& Trimble, C. (2012). Ters İnovasyon, Çeviren: H. Can Utku, Modus Kitap, 1.Bask1, İstanbul.

Gronhaug, K. \& Kaufman, G. (1988). “Introduction”, Editörler: Gronhaug, K.ve G. Kaufman, Innovation A Cross Disiplinary Perspective, Norwegian University Press, London, s.110 .

Gündüz, E. (2012), Rekabet Geriliminin Stratejik İnovasyona Etkisinin Farkındalık 
Motivasyon ve Yetenek Perspektifinde İncelenmesi, İstanbul Üniversitesi, Sosyal Bilimler Enstitüsü, İşletme Anabilim Dalı, Doktora Tezi, İstanbul.

Işık, C. \& Keskin, G. (2013). "Bilgi Ekonomilerinde Rekabet Üstünlüğü Oluşturulması Açısından İnovasyonun Önemi” Atatürk Üniversitesi İ.İ.B.F. Dergisi, 27 (1), 41-57.

İlter, B. (2008). Girişimcilik Sürecinde Kadın Girişimcilerin Karşılaştıkları Sorunların Analizi: KAGIDER Örneği, Afyon Kocatepe Üniversitesi, Sosyal Bilimler Enstitüsü, İşletme Anabilim Dal, Doktora Tezi, Afyonkarahisar.

İraz, R. (2005), Yaratıcılık ve Yenilik Bağlamında Girişimcilik ve KOBİ’ler, Çizgi Kitabevi, Konya.

İrmiş, A. \& Özdemir, L. (2011). “Girişimcilik ve Yenilik İlişkisi”, Yönetim Bilimleri Dergisi, 9(1), 139-161.

Keskin, S. (2012). “İnovasyon Nasıl Yapılır?”, Mavi Yayınları, İstanbul.

Kılıç, S. (2013). İnovasyon ve İnovasyon Yönetimi, Seçkin Yayınları, 1. Baskı, Ankara.

Kırım, A. (2007a). Alt Pazar İnovasyonu, Sistem Yayıncılık, İstanbul.

Kırım, A. (2007b). İş Modeli İnovasyonu, Sistem Yayıncılık, İstanbul.

Marangoz, M. (2012). “Girişimcilik”, Beta Yayınları, İstanbul.

Mercan, B. (2011). “Ar-Ge Faaliyetleri ve Girişimcilerin İnovasyon Üzerindeki Etkileri: Patent Verileri Üzerinde Bir Uygulama” Paradoks Dergisi, 7(2), 30-34.

Müftüoğlu, T. \& Haliloğlu, N. (2011). “Nasıl Girişimci Olunur?”, Turhan Kitabevi 2. Bask1, Ankara.

MÜSİAD (2012), Küresel Rekabet İçin Ar-Ge ve İnovasyon, Müsiad Araştırma Raporları:76, İstanbul.

Orhan, K. (2010). “Türkiye'de Büyüme İçin Olası Bir Anahtar: Bilgirişimci”, Sosyo Ekonomi, Y11:6, Say1:13-2, s.29-58.

Prahalad, C. K. \& Mashelkar. R. A. (2011). “İnovasyonun Kutsal Kasesi”, Çev. İlker Gülfidan, Harward Business Review, Mess Yayınları, Yayın No:631, İstanbul.

Robinson,S \& Stubberud, H. A. (2012).” Issues In Innovation For Norwegıan Smes” Journal of International Business Research, Cilt 11, Say1 1, s.53-61.

Sat1, Z. E. (2013), İnovasyonu Yönetmede Kesitler, Nobel Yayınları,1. Bask1, Ankara.

Seelıg, T. (2010). İnovasyon Girişimcilik Üzerine Yaratıcı Çalışmalar, Çeviren: Nuray Önoğlu, Kuraldışı Yayıncılık, İstanbul.

Tavassoli, S. \& Karlsson, C. (2015)," Persistence of various types of innovation analyzed and explained", Research Policy 44,s.1887-1901.

Tokmak, İ. (2008). Stratejik İnsan Kaynakları Yönetiminin İşletmelerin Yenilikçilik Yeteneğine Etkisi ve Elektronik Sanayisine Yönelik Bir Araştırma, Sakarya Üniversitesi, Sosyal Bilimler Enstitüsü, İşletme Anabilim Dalı, Doktora Tezi, Sakarya.

Tüylüoğlu, Ş. \& Saraç, Ş. (2012). “Gelişmiş ve Gelişmekte Olan Ülkelerde İnovasyonun Belirleyicileri: Ampirik bir Analiz” Eskişehir Osmangazi Üniversitesi, İ.İ.B.F., Dergisi, 7(1):39-74.

Uçkun, N \& Girginer, N. (2012), “Girişimciliği Etkileyen Faktörler: Eskişehir Organize Sanayi 
Bölgesindeki Metal Sektörü Girişimcilerine Yönelik Bir Uygulama”, Girişimcilik ve İnovasyon Yönetim Dergisi, 1(1), 97-113.

Uludağ, N. (2012), “Girişimciliğin Altın Kuralları”, Optimist Yayınları, İstanbul.

Ülgen, H. \& Mirze, K. (2004), İşletmelerde Stratejik Yönetim, Literatür Yayınları, 2. Bask1, İstanbul.

Zhao, F. (2005). "Exploring the Synergy Between Entrepreneurship and Innovation", Intenational Journal of Entrepreneviral Research, 11(1):25-41. 


\section{EXTENDED ABSTRACT}

\section{THE INTERACTION BETWEEN INNOVATION AND ENTREPRENEURSHIP CONCEPTS}

In the twenty-first century, innovation and entrepreneurship have become important in reaching the targets of enterprises. The entrepreneur is the person who has creativity in the formation and implementation of new ideas and plans. Entrepreneurs also have a positive influence on innovations in the presence of an entrepreneurial spirit. As entrepreneurs lean to innovation, increased quality, reduced costs, and customer expectations and needs are met in an effective way.

There are different definitions made by different authors about innovation. Drucker (1985) has defined innovation as useful information used in making knowledge and competent co-workers work efficiently. He sees innovation as a special tool of entrepreneurship (Drucker, 1985). According to the Schumpeter's notion about innovation process, commercially applicable ideas are collected and converted into products by entrepreneurs. Innovation is a tool that entrepreneurs use to create new prosperity sources or to transform available resources into additional potential.

In the classification of innovation factors such as the frequency of innovation, innovation level --in terms of customer or company--, firm value or customer benefit are important.

The innovation plays a key role for businesses to enter new markets, to increase market share and competitiveness. In this respect, regardless of sector and size, it is important, for all enterprises, to innovate and to have innovation policies. Innovations in processes and managerial activities ensure that businesses operate more efficiently and effectively. These positive results have a positive effect on growth and development of the national economy. The innovation plays an important role in sustainable growth, social welfare, increase in quality of life and dealing with unemployment.

The commitment to the systematic application of entrepreneurial innovation is - noteworthy. In addition, the use of entrepreneurial strategy and entrepreneurial management principles is another essential issue. In business world, innovation is the key to entrepreneurship, especially for public enterprises and the new progresses launched by individuals. It is important in formation of the innovation that entrepreneurs seize the opportunities and succeed.

The importance of innovation and entrepreneurship has increased even more because of democratic changes, mixed cultures, downsizing of the world, technological developments, changing networks and intense competition. Innovation is needed to be able to exist in such an environment and to be able to compete and create differences. The entrepreneur is the person who takes a long process to create value from curiosity and dreams. Entrepreneurship and innovation need to be considered in this context. Entrepreneurs who know and understand the added value of the concept of innovation gain advantage by using it. These advantages make national economies even stronger in terms of employment and sustainable growth. 